\title{
PENGARUH LAYANAN PENGUASAAN KONTEN UNTUK MENINGKATKAN KEDISIPLINAN SISWA KELAS VII F SMP NEGERI 11 KOTA BENGKULU
}

\author{
Windi Afrizal, Vira Afriyati \\ Prodi Bimbingan dan Konseling Fakultas Keguruan dan Ilmu Pendidikan \\ Universitas Bengkulu \\ Lalank.afrizal08@gmail.com,vira@konselor.org
}

\begin{abstract}
ABSTRAK
Penelitian ini bertujuan untuk mendeskripsikan pengaruh layanan penguasaan konten dengan teknik modelling dalam meningkatkan kedisiplinan siswa kelas VII F SMP Negeri 11 Kota Bengkulu. Penelitian ini merupakan penelitian eksperimen dengan desain penelitian one grup pretest dan postest. Teknik sampling yang digunakan adalah purposive sampling dimana sampel pada penelitian ini adalah siswa kelas VII F SMP Negeri 11 kota Bengkulu. Hasil yang diperoleh dalam penelitian ini menunjukkan adanya peningkatan yang signifikan pengaruh layanan penguasaan konten terhadap kedisiplinan siswa. Hal ini dapat terlihat dari hasil pengujian hipotetis dengan hasil uji t -17.988 , nilai sig sebesar $0,000(<0,005)$ maka Ho ditolak. Dapat disimpulkan, terdapat pengaruh layanan penguasaan konten dengan teknik modelling terhadap kedisiplinan siswa.
\end{abstract}

Kata kunci : layanan penguasaan konten, kedisiplinan

\section{THE INFLUENCE OF CONTENT MASTERY SERVICES IN INCREASING THE DISCIPLINE OF STUDENTS OF GRADE 7 F JUNIOR HIGH SCHOOL 11 BENGKULU CITY}

\begin{abstract}
The aim of this study was to describe the effect of content mastery service by using modelling technique in improving the discipline of VII F grade students of junior high school 11 bengkulu city. This study was an experimental research with one group pretest and post test research design. The purposive sampling was used as the sampling technique where the sample in this research was VII F grade students of junior high school 11 bengkulu city. The result of this study showed that there was a significant improvement in conten mastery service toward students discipline. It could be showed from the result of hypothesis testing with the result of t-testing 17,988, with significant (sig) value $0.000(<0,005)$ so the Ho was rejected. It can conclude that there was an effect of content mastery service with modelling technique toward students discipline.
\end{abstract}

Keywords : content mastery services, discipline 


\section{Pendahuluan}

Pendidikan adalah aspek universal yang selalu harus ada dalam diri manusia. Pendidikan merupakan salah satu hal yang sangat penting untuk anak-anak Indonesia, seperti yang tertera dalam Pasal 1 Ayat (1) UU No. 20/2003 tentang sistem Pendidikan Nasional menyatakan bahwa Pendidikan adalah usaha sadar dan terencana untuk mewujudkan suasana belajar dan proses pembelajaran agar peserta didik secara aktif mengembangkan potensi dirinya untuk memiliki kekuatan sprititual keagamaan, pegendalian diri, kepribadian, kecerdasan, akhlak mulia serta keterampilan yang diperlukan dirinya, masyarakat, bangsa dan negara.

Sekolah merupakan tempat peserta didik (siswa) memperoleh materi pendidikan. Sekolah tidak hanya digunakan sebagai sarana siswa untuk memperoleh kognitifnya saja, tetapi juga sebagai sarana untuk belajar untuk menjadi mandiri, tekun, dan tentunya disiplin dalam segala hal. Oleh karena itu diperlukan berbagai macam kompetensi dan kecakapan hidup yang harus dimiliki oleh setiap siswa agar mampu menciptakan generasi yang mempunyai kualitas dan jiwa saing tinggi. Salah satu kompetensi tersebut adalah kedisiplinan.

Disiplin merupakan bentuk perilaku patuh dan tunduk terhadap peraturan yang berlaku tetapi kepatuhan itu lebih ditekankan pada kesadaran diri bukan karena paksaan. Akan tetapi pada kenyataannya banyak perilaku disiplin manusia yang dilatar belakangi karena adanya paksaan atau aturan yang mengekang. Sehingga asumsi yang berkembang di kalangan para siswa bahwa disiplin itu itu berarti kaku dan menakutkan.

Mengutip pernyataan dari Durkheim (1990:35) yang menyebutkan bahwa disiplin mempunyai tujuan ganda yaitu untuk mengembangkan suatu keteraturan dalam tindak-tanduk manusia dan memberikan suatu sasaran tertentu yang sekaligus juga membatasi cakrawalanya. Selain itu Rimm (2003:47) mengungkapkan bahwa disiplin mempunyai tujuan untuk mengarahkan anak agar mereka belajar mengenai hal-hal baik yang merupakan persiapan bagi masa dewasa, saat mereka sangat bergantung pada disiplin diri. Berdasarkan dua teori tersebut dapat diketahui bahwa disiplin sangat penting untuk menjadikan individu lebih terarah dalam menjalankan kehidupannya.

Masalah kedisiplinan ini biasanya bermula terjadi pada anak-anak yang baru menginjak usia remaja khususnya pada fase pendidikan menengah pertama seperti pengamatan yang dilihat dari peneliti di SMP Negeri 11 Kota Bengkulu dimana masih banyak murid disana yang belum bisa mengikuti tata tertib sekolah dengan baik, padahal SMP Negeri 11 kota 
Bengkulu merupakan salah satu sekolah menengah pertama dengan standar Nasional yang sudah diberi gelar sekolah adiwiyata oleh nasional.

Berdasarkan hasil pengamatan selama melaksanakan praktik magang 2 yang dilaksanakan pada tanggal 20 September-21 Desember2019 oleh pihak unit PPL Fakultas Keguruan dan Ilmu Pendidikan Universitas Bengkulu di SMP Negeri 11 Kota Bengkulu peneliti melihat atau menangkap banyaknya siswa yang melanggar tata tertib sekolah. Pelanggaran-pelanggaran yang kebanyakan dilakukan oleh siswa yaitu sering terlambat datang kesekolah, sering keluar masuk ketika jam pelajaran, berpakaian kurang rapi dan membolos ketika jam sekolah.

Salah satu layanan yang dapat digunakan untuk meningkatkan disiplin siswa adalah dengan menggunakan layanan penguasaan konten. Layanan penguasaan konten merupakan layanan yang mempunyai fungsi agar seseorang dapat menguasai suatu konten tertentu untuk menambah wawasan dan pemahaman, mengarahkan penilaian sikap, menguasai cara atau kebiasaan tertentu untuk memenuhi kebutuhannya dan mengatasi masalah-masalahnya (Prayitno, 2004:2).

Mengacu pada penjelasan sebelumnya maka peneliti tertarik untuk melakukan penelitian dengan judul "Pengaruh layanan penguasaan konten dalam meningkatkan kedisiplinan siswa kelas VII F SMP Negeri 11 Kota Bengkulu Tahun Ajaran 2018/2019”.

\section{Metode Penelitian}

Metode yang digunakan dalam penelitian ini adalah metode penelitian quassy eksperimen dengan cara memberikan layanan penguasaan konten kepada kelompok eksperimen. Desain dalam penelitian ini adalah pre-eksperimental desain dengan jenis onegroup pretest-posttest design. Penelitian ini digunakan untuk mengetahui adanya pengaruh suatu tindakan terhadap suatu variabel. Variabel yang digunakan untuk memprediksi disebut variabel prediktor atau variabel bebas (independent). Variabel yang diprediksi disebut variabel kriterium/criteria atau variabel terikat (dependent). Teknik pengambilan sampel ini dengan menggunakan cara purposive sampling.

Teknik pengumpulan data yang digunakan dalam penelitian ini adalah melalui penyebaran angket/instrumen yang berupa angket kedisiplinan siswa. Peneliti melakukan pengumpulan data penelitian dengan cara menggunakan angket kedisiplinan siswa dengan menggunakan skala Likert. Skala Likert adalah skala yang digunakan untuk mengukur sikap, pendapat, dan persepsi seseorang atau kelompok orang terhadap suatu kejadian atau keadaan sosial dimana variabel yang dijabarkan menjadi indikator-indikator yang dapat diukur. 
Menurut Sukmadinata, Nana S (2011: 225), skala merupakan teknik pengumpulan data yang bersifat mengukur, karena diperoleh hasil ukur yang berbentuk angka-angka. Skala berbeda dengan tes, kalau tes ada jawaban benar atau salah, sedangkan skala tidak ada jawaban benar-salah, tetapi jawaban atau respon responden terletak dalam satu rentang (skala).

Uji validitas dalam penelitian ini menggunakan validitas isi. Menurut Bungin (2005: 107), validitas isi dimaksudkan bahwa isi atau bahan yang diuji atau dites relevan dengan kemampuan, pengetahuan, pelajaran, pengalaman atau latar belakang. dilakukan juga uji daya beda item, angka yang menunjukkan bedarnya daya beda disebut indeks diskriminasi disingkat $D$. Pada penelitiaan ini peneliti menggunakan batas nilai $D>0,30$. Jika dibawahnya maka item dinyatakan gugur. Sehingga item yang tersisa hanya 29 butir yang semula berjumlah 52 butir soal. Perlakuan yang diberikan dalam penelitian yaitu layanan penguasaan konten dengan 6 kali pertemuan yang dilaksanakan di dalam kelas VII F SMP N 11 Kota Bengkulu.

\section{Hasil dan Pembahasan}

Dalam menentukan kategori perolehan skor siswa dilakukan terlebih dahulu perhitungan untuk mencari mean dan standar deviasi. Kuesioner kedisiplinan siswa yang terdiri atas 29 item dengan 5 pilihan jawaban yang bergerak dari 1 sampai 5, sehingga diperoleh rentang minimum adalah 29 × $1=29$ maximum adalah 29 × $5=145$ dan meannya adalah 87 , serta satuan deviasi standarnya bernilai 19,3. Pengukuran menggunakan 5 kategori, kategori tersebut adalah sangat tinggi, tinggi, sedang, rendah, dan sangat rendah

\section{Tabel 1}

\section{Frekuensi Pre-test Kedisiplinan Siswa}

\begin{tabular}{ccc}
\hline Interval & Frekuensi & Persentase \\
\hline Sangat tinggi $>\mathbf{1 1 6}$ & 0 & 0 \\
\hline Tinggi $\mathbf{9 7 - 1 1 5}$ & 5 & 16 \\
\hline Sedang 87-96 & 11 & 34 \\
\hline Rendah $\mathbf{7 7 - 8 6}$ & 15 & 47 \\
\hline Sangat rendah $<\mathbf{7 7}$ & 1 & 3 \\
\hline Total & 32 & 100 \\
\hline
\end{tabular}

Hasil pengolahan pre-test dapat disimpulkan bahwa siswa yang mempunyai tingkat kedisiplinan dengan kategori tinggi dengan rentang skor 97 - 115 berjumlah 5 siwa, kategori sedang dengan rentang skor 87 - 96 terdapat 11 orang siswa, kategori rendah dengan rentang 
skor 77 - 86 berjumlah 15 siswa, dan kategori sangat rendah dengan rentang skor <77 berjumlah 1 siswa.

Berdasarkan hasil tersebut dapat diketahui bahwa tingkat kedisiplinan siswa dalam mentaati tata tertib dengan kategori sangat tinggi, tinggi, sedang, rendah, dan sangat rendah. Langkah selanjutnya diberikan layanan penguasaan konten agar siswa yang memiliki tingkat kedisiplinan sedang dan rendah mengalami perubahan peningkatan tingkat kedisiplinan siswa dalam mentaati tata tertib setelah diberikannya layanan penguasaan konten untuk mencegah terjadinya pelanggaran tata tertib yang dilakukan oleh siswa.

Angket kedisiplinan kembali diberikan kepada siswa kelas VII F, setelah diberikan layanan penguasaan konten kepada siswa yang tingkat kedisiplinannya rendah. Angket yang diberikan pada post-test sama dengan angket yang diberikan pada saat pre-test.

\section{Tabel 2}

Frekuensi Post-Test Kedisiplinan Siswa

\begin{tabular}{ccc}
\hline Interval & Frekuensi & Persentase \\
\hline Sangat tinggi $>$ 116 & 11 & 34 \\
\hline Tinggi 97-115 & 15 & 47 \\
\hline Sedang 87-96 & 6 & 19 \\
\hline Rendah 77-86 & 0 & 0 \\
\hline Sangat rendah <77 & 0 & 0 \\
\hline Total & 32 & 100 \\
\hline
\end{tabular}

Dari hasil pengolahan post-test dapat disimpulkan bahwa ada perubahan peningkatan kedisiplinan siswa sebelum dilaksanakan (pre-test) dan setelah dilaksanakan (post-test), serta diberikan layanan penguasaan konten dengan teknik modelling. Dari 32 siswa yang diberikan perlakuan layanan penguasaan konten dengan teknik modelling, mengalami perubahan peningkatan tingkat kedisiplinan siswa dalam mentaati tata tertib yakni dengan kategori sangat tinggi ketentuan skor $>116$ berjumlah 11 orang, dengan kategori tinggi ketentuan skor 97 - 115 berjumlah 15 orang, serta dengan kategori sedang ketentuan skor 87 - 96 berjumlah 6 orang.

Sebelum diberikan layanan penguasaan konten terhadap kedisiplinan siswa terlebih dahulu peneliti melakukan pre-test pada siswa yang akan dijadikan sampel yakni kelas VII F sebanyak 32 orang siswa dengan instrumen tes sebanyak 29 butir soal yang telah diuji 
validitasnya dengan menggunakan aplikasi statistical packages for social science (SPSS) for windows release 16. Dimana hasil pre-test sebelum diberikan layanan penguasaan konten menunjukan bahwa tingkat kedisiplinan siswa dengan kategori tinggi dengan rentang skor 97 - 115 berjumlah 5 siwa, kategori sedang dengan rentang skor 87 - 96 terdapat 11 orang siswa, kategori rendah dengan rentang skor 77 - 86 berjumlah 15 siswa, dan kategori sangat rendah dengan rentang skor $<77$ berjumlah 1 siswa. Dapat disimpulkan bahwa kedisiplinan siswa sebelum diberikan layanan penguasaan konten adalah rendah.

Menurut Tu'u (2004: 48) menyebutkan bahwa ada beberapa faktor yang mempengaruhi kedisiplinan yaitu sebagai berikut: (1) Kesadaran diri, (2) Pengikutan dan ketaatan, (3) Alat pendidikan, (4) Hukuman. Dari semua faktor yang mempengaruhi kedisiplinan siswa tersebut baik faktor internal dan eksternalnya dapat disimpulkan bahwa rendahnya hasil test yang diperoleh siswa kelas VII F diakibatkan karena rendahnya kesadaran siswa akan pentingnya kedisiplinan dalam mentaati tata tertib dan kurangnya alat pendidikan yang mendukung untuk mendisiplinkan siswa, sehingga siswa tidak mampu mengembangkan pola pikir mereka untuk menjadi disiplin.

Penelitian ini dianggap penting diberikan responden kelas VII F SMP N 11 Kota Bengkulu karena melihat secara umum bahwa siswa mempunyai kategori rendah dalam mentaati tata tertib sekolah. Hal ini dilakukan karena salah satu fungsi utama dari layanan penguasaan konten adalah pemeliharaan dan pengembangan. Sesuai dengan yang diungkapkan oleh Prayitno (2004: 3) bahwa penguasaan konten dapat secara langsung maupun tidak langsung mengembangkan disatu sisi, dan disisi yang lain memelihara potensi individu atau klien. Apabila dikaitkan dengan penelitian ini berarti layanan penguasaan konten ini berfungsi untuk meningkatkan kedisiplinan siswa yang mempunyai tingkat kedisiplinan rendah menjadi lebih baik, dan memelihara serta mengembangkan kondisi kedisiplian siswa yang berada pada kategori sedang dan kategori tinggi menjadi semakin baik, terarah dan berkelanjutan.

Setelah diberikan layanan penguasaan konten terhadap kedisiplinan siswa terjadi peningkatan skor hasil tes siswa, hal ini terlihat dari hasil post-test yang telah diberikan. dari 32 siswa yang diberikan perlakuan layanan penguasaan konten dengan teknik modelling, mengalami perubahan peningkatan tingkat kedisiplinan siswa dalam mentaati tata tertib yakni dengan kategori sangat tinggi ketentuan skor >116 berjumlah 11 orang, dengan kategori tinggi ketentuan skor 97 - 115 berjumlah 15 orang, serta dengan kategori sedang ketentuan skor 87 - 96 berjumlah 6 orang. 
Menurut Supriyo (2010:38) menjelaskan bahwa fungsi pemeliharaan dan pengembangan adalah fungsi bimbingan dan konseling yang akan menghasilkan terpeliharanya dan berkembangnya berbagai potensi dan kondisi positif peserta didik dalam rangka perkembangan dirinya secara mantap dan berkelanjutan. Dengan layanan penguasaan konten diharapkan dapat membantu siswa mengembangkan potensi yang ada dalam diri siswa sehingga siswa mampu untuk meningkatkan kedisiplinan siswa dalam mentaati tata tertib sekolah.

Hasil hipotesis yang telah dilakukan menunjukan signifikansi 0,000<0,005 yang berdasarkan kriteria penerimaan atau penolakan hipotesis, Ho ditolak dan Ha diterima maka diperoleh hasil bahwa ada perbedaan yang signifikan kedisiplinan siswa sebelum dan sesudah diberikan layanan penguasaan konten pada siswa kelas VII F. Dari hasil pre-test dan post-test juga menunjukkan bahwa secara keseluruhan rendahnya kedisiplinan siswa menjadi tinggi setelah mendapatkan treatment. Apabila dikaitkan pada hipotesis yang ingin dibuktikan pada penelitian ini maka dapat dibuktikan bahwa kedisiplinan siswa dapat ditingkatkan melalui layanan penguasaan konten dengan menggunakan teknik modelling pada siswa SMP Negeri 11 Kota Bengkulu.

Dari hasil tersebut dapat disimpulkan bahwa layanan penguasaan konten sangat berpengaruh dalam meningkatkan kedisiplinan siswa. Sesuai dengan pendapat Prayitno (2004: 2) layanan penguasaan konten merupakan layanan bantuan yang diberikan kepada individu (sendiri-sendiri ataupun kelompok) untuk menguasai kemampuan atau kompetensi tertentu melalui kegiatan belajar.

Berdasarkan uraian di atas maka dapat disimpulkan bahwa layanan penguasaan konten merupakan suatu layanan untuk mendapatkan suatu pemahaman dan menguasai kompetensi diri maupun kelompok melalui proses kegiatan belajar. Penggunaan teknik modelling sangat cocok menurut peneliti sebagai alat untuk membantu layanan penguasaan konten untuk meningkatkan kedisiplinan siswa dalam mentaati tata tertib. Hal ini sesuai dengan yang dikemukakan oleh Bandura (dalam Feist, 2008:409) bahwa pembelajaran dengan mengamati jauh lebih efisien daripada pembelajaran dengan mengalami langsung. Dengan mengamati orang lain, manusia mempelajari respon mana yang diikuti penghukuman atau yang tidak diikuti penguatan.

\section{Kesimpulan}

Tingkat kedisiplinan siswa dalam mentaati tata tertib sebelum diberikan layanan penguasaan konten pada siswa kelas VII F SMP N 11 Kota Bengkulu tahun ajaran 2019/2020 
berada pada kategori rendah. Kedisiplinan siswa dalam mentaati tata tertib setelah diberikan layanan penguasaan konten mengalami peningkatan. Hal ini ditunjukkan dengan adanya peningkatan skor kedisiplinan siswa setelah diberikan layanan penguasaan konten yang dapat dilihat dari hasil post-test siswa setelah diberikan layanan. Terdapat perubahan yang positif yaitu berupa peningkatan yang signifikan pada kedisiplinan siswa dalam mentaati tata tertib setelah diberi layanan penguasaan konten pada siswa kelas VII F SMP Negeri 11 Kota Bengkulu tahun ajaran 2019/2020. Hasil ini di dukung dengan pengamatan terhadap responden selama penelitian dan melihat dari hasil peningkatan skor post-test.

Bagi Guru pembimbing hendaknya untuk bisa memberikan layanan sesuai dengan kebutuhan siswa dan memanfaatkan setiap waktu yang ada untuk perkembangan siswa untuk meningkatkan kedisiplinan siswa dalam mentaati tata tertib sekolah. Bagi siswa dengan diberikannya layanan penguasaan konten hendaknya siswa dapat memahami serta menerapkan apa yang telah disampaikan peneliti agar dapat mencegah terjadinya pelanggaran tata tertib di sekolah. Bagi sekolah pihak sekolah hendaknya menjadikan hasil penelitian ini untuk menambah referensi serta menambah wawasan kepada pihak sekolah dalam memberikan layanan bimbingan dan konseling untuk siswa di sekolah. Bagi peneliti, peneliti lanjutan hendaknya menjadikan penelitian ini sebagai referensi untuk penelitian selanjutnya supaya lebih sempurna dan digunakan dengan sebaik-baiknya dan bermanfaat.

\section{Daftar Pustaka}

Bungin, B. 2005. Metodologi penelitian kuantitatif. Jakarta : Salemba Human

Durkheim, E. 1990. Pendidikan Moral Suatu Studi Toeri dan Aplikasi Sosiologi Pendidikan. Jakarta: Erlangga

Emzir. 2015. Metodologi Penelitian Pendidikan. Jakarta: Raja Grafindo Persada.

Prayitno dan Amti, Erman. 2004. Dasar-dasar Bimbingan Dan Konseling. Jakarta: Rineka Cipta

Prayitno. 2004. L.1-L.9. Padang. Universitas Negeri Padang.

Rimm, S. 2004. Mendidik dan Menerapkan Disiplin pada Anak Prasekolah. Jakarta: Gramedia

Roshita ita. 2014. Meningkatkan Kedisiplinan Siswa Melalui Layanan Bimbingan Kelompok Dengan Teknik Modelling. Jurnal BK UNS. Semarang. Vol 15. No 4. Hal 46-51.

Sugiyono.2009. Statistik untuk Penelitian. Bandung.Penerbit: Alfabeta.

Suhada, Idad. 2006. Strategi Guru dalam Meningkatkan Kedisiplinan Siswa Terhadap Berbagai Peraturan Sekolah : Studi Implementasi dan Ketakwaan di SMAN 1 Sukawening Garut. Jurnal UNS. Semarang Vol 3. No 1. Hal 17-30

Sukmadinata, N. 2011. Metode Penelitian Pendidikan. Bandung: Remaja Rosdakarya. 
ISSN 2599-1221 (Cetak)

ISSN 2620-5343 (Online)

Supriatna, M. 2011. Bimbingan dan konseling berbasis kompetensi. Jakarta. Penerbit : PT Raja Grafindo Persada

Tu’u, Tulus. 2004. Peran Disiplin Pada Perilaku dan Prestasi Siswa. Jakarta: Grasindo 